\title{
Entomotoxicity Properties of Eco-Friendly Crude Protein Extract From Manilkara Zapota Seed against Asian Tiger Vector Aedes Aegypti
}

\author{
Ezhumalai Parthiban', Ravichandran Ramanibai ${ }^{1 *}$ \\ ${ }^{1}$ Department of Zoology, Unit of Aquatic Biodiversity, University of Madras, Guindy Campus Chennai
}

Received: 23 November, 2016; Accepted: 18 January, 2017; Published: 30 January, 2017

*Corresponding author: Ravichandran Ramanibai, Department of Zoology, Unit of Aquatic Biodiversity, University of Madras, Guindy Campus Chennai, Tel.: 91+-44-22202833; fax: 044-22300899; E-mail: rramani8@hotmail.com

\begin{abstract}
The present study is aimed to carry out larvicidal activity of crude protein extract from M. zapota seed against all the four instars of Aedes aegypti. The crude protein exposed to larvae with various concentration of 1 to $10 \mathrm{mg} / \mathrm{mL}$ for $24 \mathrm{hrs}$. The larvicide percent mortality shows predominantly were as $100,87.5$ and $72.5 ; 92.5,75$ and 50; 77.5, 62.5 and 55; 65, 50 and 35 at 6 to $3 \mathrm{mg} / \mathrm{mL}$ against first to fourth instars larvae of $A$. aegypti, respectively. The mortality of lethal concentration were as $\left(\mathrm{LC}_{50} 2.64\right.$ to $\left.4.68 \mathrm{mg} / \mathrm{mL}\right)$ and followed by $\mathrm{LC}_{90}$ is 6.24 to $8.33 \mathrm{mg} / \mathrm{mL}$ against of first to fourth instars larvae of $A$. aegypti respectively. The crude protein had a special hemolytic activity with different vertebrate erythrocytes such as sheep, goat, cow, ox and buffalo among which ox has produced higher HA titer value of 128 respectively. Moreover the plant seed crude protein did not cause any mortality to the non-target organism tested against Cladoceran, Moina micrura. The result clearly displays that $M$. zapota seed crude protein has efficient larvicidal activity against Aedes aegypti with significantly $(P<0.05)$. Further study to be needed to purify and characterize the active insecticidal macromolecule present in the plant crude protein extract against dengue vector.
\end{abstract}

Keywords: Aedes Aegypti; Hemolytic activity; Cladoceran; Moina micrura

\section{Introduction}

Vector control are most important task to prevent the viral disease spreading insect due to caused transmitted disease between the populations worldwide, especially the Aedes aegypti belongs to arthropod insect transmitted disease called dengue hemorrhagic fever and chikungunya [1]. Dengue is the fastest growing mosquito borne viral infection and its impact today is 30 times greater than 50 years ago. As recently as the 1970 s, less than 10 countries had reported epidemics of severe dengue. These days, dengue is present in over 150 countries and The WHO estimates that about $40 \%$ of the world's population being infected with dengue to all age groups is at risk. According to the World Health Organization (WHO), there are about 390 million cases of dengue fever worldwide in both developed and developing countries [2]. In India, official records of the Union Health Ministry reveal an immense increase in dengue infections every year [3]. Due to adverse environmental effects associated with chemical insecticides have led to the search for an alternative methods for controlling different disease-transmitting mosquito species [4]. Over the past 20 years, botanical insecticides have thrown an attention as new approaches to insect control [5]. In India has rich in aromatic plant diversity with potential for development of natural insecticides for control of mosquito and other pests [6]. In this regards plant seed contain several biologically active proteins that play a various specialized functions, in these the most representative molecules are hydrolytic enzymes, inhibitors, lectins and the ribosome inactivating proteins $[7,8]$. Among these several insecticidal molecules, the lectin play a major role in control of several insect pest order such as Coleoptera, Diptera, Lepidoptera and Homoptera, due to these protein can act as recognition molecules in cell-cell or cell-matrix interactions [9] and may bind to the peritrophic membrane and especially it has ability to bind to carbhohydrate chain moieties on insect gut membrane and it has some characteristic features that these protein are resistant to proteolytic degradation by insect digestive enzymes, therefore it has inhibit the food digestion, absorption and consequentially the larvae was dead. [9-12]. Lectin from Myracrodroun heartwood, bark and leaf showed effective larvicidal activity of Aedes aegypti [13]. In addition, Coelho et al [14] reported that WSMoL showed larvicidal activity in the lethal concentration values of $\left(\mathrm{LC}_{50} 0.197\right.$ $\mathrm{mg} / \mathrm{mL})$ against the $\left(\mathrm{L}_{4}\right)$ of Aedes aegypti. The Manilkara zapota belongs to the family of sapotacea, Genus: Manilkara, Species: zapota and it has become a major commercial crop in India. It is growing to a height of around 8 meters. The bark is dark brown and deeply fissured and fruit is brown, fleshy, ovoid to round 3-8 cms long and fruit containing 5 or more shiny blackish brown seeds [15-17]. The plant material has various biological activities such as the leaves have larvicidal activity of Haemaphysalis bispinosa, Hippobosca maculata, and Anopheles subpictus [18] anti-microbial, antibacterial $[19,20]$ and antioxidant properties [21]. Seed protein are small hydrophilic proteins, ranging from 83 to 153 amino acid residues, performing a number of crucial physiological function mainly seed has sapling defense [22]. Till date there is no report available using crude protein extract to 
evaluate the mosquito larvicidal activity in this plant material. Therefore we here designed this study to evaluate the larvicidal activity of Manilkara zapota seed crude protein against various larval instars of Aedes aegypti.

\section{Material and Methods}

\section{Collection and Identification of Plant Materials}

The full mature ripened fruit seeds were collected from the surrounding area of kotturpuram and Guindy, Chennai, India in 2016. The identity of the plant material was verified by the taxonomist, Prof. T. Balasubramanium, Department of Advanced Studies in Botany at University of Madras, India.

\section{Preparation of Plant Extracts}

The collected plant material was thoroughly washed with distilled water and shade dried at RT. The dried seed coat was removed manually; after this coat removed it was powdered by using an electric grinder. These powders were stored in air tight container and kept in $4^{\circ} \mathrm{C}$. The finely grinded powder was subjected into $5 \%$ Hexane to remove the fat content. According to methodology followed by Zeng [23] with slight modification, the dried plant seed powder was subjected into $50 \mathrm{mM}$ Tris- $\mathrm{HCl}$ and $115 \mathrm{mM} \mathrm{NaCl}$ in the range of $(1: 10)$ at $\mathrm{pH} 7.4$ the mixture was under magnetic stirred at cooled room temperature for 4 $\mathrm{hr}$. The stirred material was centrifuged at $15000 \mathrm{rpm}$ for 20 minutes. The supernatant was filtered and stored until bioassay performed.

\section{Spectrophotometric Determination of Protein}

The crude protein extract $(0.1 \mathrm{ml})$ was added to $2 \mathrm{ml}$ containing lowery's reagent solution in $5 \mathrm{ml}$ glass tube and then mixed thoroughly and incubated for $10 \mathrm{~min}$ 's. An aliquot amount of $0.2 \mathrm{ml}$ of folin ciolteau's $(1: 1)$ reagent was added to the reaction mixture and kept it for 30 minutes at Rt. The Optical density of reaction solution was read by Folin -lowery method [24] at 650 nm with BSA using as standard.

\section{Determination of Hemolytic Activity}

Hemolytic assay was performed with erythrocytes using, the technique previously described by [25]. The crude plant protein of M. zapota 25 ul were serially diluted to each well containing the same volume of $25 \mathrm{ul}$ TBS buffer, $\mathrm{pH} 7.4$, then $25 \mathrm{ul}$ of $1.5 \%$ various vertebrate RBC suspension was added in 96 well ' $\mathrm{V}$ ' bottom microtitre plate. The microtitre plate was kept at $37^{\circ} \mathrm{C}$ for $45 \mathrm{~min}$ 's for formation of lytic activity observation.

\section{Insect Collection and Rearing}

Aedes aegypti [figure 1] larvae were collected from the artificial made container at University of Madras Guindy campus and Adyar house hold areas, Chennai in the period time of NovDec, 2015. The larvae were kept in plastic and enamel tray (30 $\mathrm{cm} \times 15 \mathrm{~cm} \times 6.5 \mathrm{~cm}$ ) and maintained under laboratory condition $(26 \pm 2)^{\circ} \mathrm{C}$ with photoperiod of 12:12 h (Light: Dark) and larvae Feed with dog biscuit: yeast $(3: 1 ; w / w)$ was regular provided. After pupation the pupae were maintained in mosquito cages at
$26 \pm 2^{\circ} \mathrm{C}$ and relative humidity of $75 \pm 3 \%$ under a photoperiod of 12:12 h (L:D) for adult emergence. Required cotton was soaked in $10 \%$ aqueous glucose solution and put in petri plate to feed adult male mosquitoes. An immobilized rat kept in small cage and put into mosquitoes cage for $3 \mathrm{~h}$ to provide blood meal to Female mosquitoes. A plastic tray $(11 \times 10 \times 4 \mathrm{~cm})$ filled with tap water with a lining of partially immersed filter paper and then placed inside of the cage to enable, the female mosquitoes to lay their eggs. The eggs obtained from the laboratory-reared mosquitoes and immediately allowed to hatch out under the controlled laboratory conditions as described above. Only the newly hatched specific instars of larvae were used in all bioassays.

\section{Laboratory Bioassays}

The larvicidal bioassay was performed by according to WHO [26] with some modification. The different concentration (1 to $10 \mathrm{mg} / \mathrm{mL}$ ) of crude protein was prepared from stock solution and was diluted to $50 \mathrm{ml}$ of tap water containing bowl, in each concentration 10 number of different (I to IV) instars A. aegypti were introduced and each assay was performed four replicates. The numbers of dead larvae were counted after $24 \mathrm{~h}$ of exposure to plant material, the percentage of mortality was reported from the average of four replicates. The control was set up with TBS buffer.

\section{Non-Toxicity Test}

The Cladoceran, crude protein were collected from the freshwater pond of Velachery lake, Tamilnadu, India and it was exposed at different concentrations ( 1 to $10 \mathrm{mg} / \mathrm{mL}$ ) of plant extract prepared from stock solutions, according to method recommended by Economic Co-operation and Development Guideline 202 for testing of Chemicals to aquatic organisms acute immobilization test [27]. The each concentration ten number of strains were subjected into the extract.

\section{Statistical Analysis}

The LC50 and LC90 values were calculated after $24 \mathrm{~h}$ by probit analysis and 95\% class upper and lower confidence limits and chi-square values obtained using statplus v.5.

\section{Result}

\section{Medicative Importance of Plant Extract and Yield}

The details about the medicinal plant tested, M. zapota for the bioactivity against different instars of $A$. aegypti are shown in [Table 1]. The crude protein extracted using various buffer at their optimum reducing environment, among the various buffer extraction, the TBS (50mM Tris buffer and $110 \mathrm{mM}$ saline) pH, 7.4 extracted to obtain maximum protein concentration level (Data not shown).

\section{Determination of Lectin Activity}

Thecrude protein was analyzed to detect the Hemagglutination activity with various vertebrate RBC suspensions, such as sheep, Goat, Cow, Ox and Buffalo. Among the various RBC tested, interestingly it agglutinated with all vertebrate $\mathrm{RBC}$ without any divalent cation requirements and higher HA titer value is 
Table 1: LC50, LC90, and other statistical analysis of M. zapota seed crude protein against first to fourth instars larvae of A. aegypti

\begin{tabular}{|c|c|c|c|c|c|c|c|}
\hline Species & Stage & Concentration & Percent mortality \pm S.D & LC $_{50}$ (LCL- UCL) & LC $_{90}$ (LCL-UCl) & Slope & $X^{2}(\mathrm{df}=8)$ \\
\hline & & 1 & $22.5 \pm 0.5$ & & & & \\
\hline & & 2 & $47.5 \pm 0.5$ & & & & \\
\hline & & 3 & $60 \pm 1.41$ & & & & \\
\hline & & 4 & $72.5 \pm 0.5$ & & & & \\
\hline & $I^{\text {st }}$ instar & 5 & $87.5 \pm 0.5$ & $2.64(1.56-2.83)$ & $6.24(4.09-7.46)$ & 47.5 & 1.12 \\
\hline & & 6 & $100 \pm 0.0$ & & & & \\
\hline & & 7 & $100 \pm 0.0$ & & & & \\
\hline & & 8 & $100 \pm 0.0$ & & & & \\
\hline & & 9 & $100 \pm 0.0$ & & & & \\
\hline & & 10 & $100 \pm 0.0$ & & & & \\
\hline & & 1 & $15 \pm 0.57$ & & & & \\
\hline & & 2 & $35 \pm 1.2$ & & & & \\
\hline & & 3 & $50 \pm 0.81$ & & & & \\
\hline & & 4 & $62.5 \pm 0.95$ & & & & \\
\hline & & 5 & $75 \pm 0.57$ & & & & \\
\hline & & 6 & $92.5 \pm 0.95$ & $3.19(2.23-3.66)$ & $6.72(4.84-8.12)$ & 35 & 0.77 \\
\hline & II nd instar & 7 & $100 \pm 0.0$ & & & & \\
\hline & & 8 & $100 \pm 0.0$ & & & & \\
\hline & & 9 & $100 \pm 0.0$ & & & & \\
\hline \multirow[t]{21}{*}{ A. aegypti } & & 10 & $100 \pm 0.0$ & & & & \\
\hline & & 1 & $12.5 \pm 0.5$ & & & & \\
\hline & & 2 & $27.5 \pm 0.5$ & & & & \\
\hline & & 3 & $45 \pm 0.57$ & & & & \\
\hline & & 4 & $55 \pm 0.57$ & & & & \\
\hline & & 5 & $62.5 \pm 0.95$ & & & & \\
\hline & III rd instar & 6 & $77.5 \pm 0.5$ & $3.45(2.61-4.22)$ & $7.75(6.40-12.18)$ & 27.5 & 2.06 \\
\hline & & 7 & $87.5 \pm 0.5$ & & & & \\
\hline & & 8 & $100 \pm 0.0$ & & & & \\
\hline & & 9 & $100 \pm 0.0$ & & & & \\
\hline & & 10 & $100 \pm 0.0$ & & & & \\
\hline & & 1 & $10 \pm 0.81$ & & & & \\
\hline & & 2 & $17.5 \pm 0.5$ & & & & \\
\hline & & 3 & $25 \pm 0.57$ & & & & \\
\hline & & 4 & $35 \pm 0.57$ & & & & \\
\hline & IV th instar & 5 & $50 \pm 0.81$ & $4.68(3.87-5.44)$ & 8.33 (7.19-12.01) & 90 & 1.56 \\
\hline & & 6 & $65 \pm 1.29$ & & & & \\
\hline & & 7 & $77.5 \pm 1.25$ & & & & \\
\hline & & 8 & $90 \pm 0.81$ & & & & \\
\hline & & 9 & $100 \pm 0.0$ & & & & \\
\hline & & 10 & $100 \pm 0.0$ & & & & \\
\hline
\end{tabular}

Control- nil mortality, $\mathbf{L C}_{50}$ - lethal concentration that kills $50 \%$ exposed larvae, $\mathbf{L C}_{90}$ - lethal concentration that kills $90 \%$ of exposed larvae to the plant extract, $\mathbf{L C L}=$ lower confidence limit, $\mathbf{U C L}=$ upper confidence limit, $\boldsymbol{d} \boldsymbol{f}=$ degree of freedom, $\boldsymbol{x}^{2}=$ chi square, $p<0.05$ level of significant. 
obtained to Cow as 128, when compared to other vertebrate erythrocytes as shown [Table 2]. Moreover these M. zapota seed crude protein did not show the agglutinin activity, which has ability to lysis the various RBC tested in this experiment, when repeated several times using erythrocytes. Therefore the plant extract has properties of hemolytic activity against Erythrocytes.

\section{Mortality}

The different instars (I to IV) of A. aegypti larvae [Figure 1] tested using plant extract and confirm larvicidal activity against the dengue vector. Which has obtained maximum mortality rate at their 5 to $6 \mathrm{mg} / \mathrm{mL}$ against all four instars shown in [Table 1].The higher mortality rate $(100 \%)$ of different instar has obtained at different concentration with significantly exposure to plant extract for $24 \mathrm{~h}$. As shown in [Table 1] the crude protein elicit at maximum percent mortality rate at 6 to $1 \mathrm{mg} / \mathrm{mL}$ were $100,87.5,72.5,60,47.5$ and 22.5 for first instar; $92.5,75,62.5,50$, 35 and 15 for second instar; 77.5, 62.5, 55.5, 45, 27.5 and 12.5 for third instar; $65,50,35,25,17.5$ and 10 for fourth instar larvae of A. aegypti respectively. Therefore the rate of mortality is directly proportional to dose dependently increased the concentration.

\section{Lethal Effect}

The lethal concentration is very correspondently important to obtained larval mortality without any harmful effect on environment, which has safe and identify the actual concentration to produce the required larval mortality in the range of 50 and

Table 2: Hemolytic titer value of different erythrocytes

\begin{tabular}{|c|c|}
\hline Erythrocytes & Titer value \\
\hline Sheep & $5^{2}$ \\
\hline Goat & $6^{2}$ \\
\hline Cow & $7^{2}$ \\
\hline Ox & $8^{2}$ \\
\hline Buffalo & $5^{2}$ \\
\hline
\end{tabular}

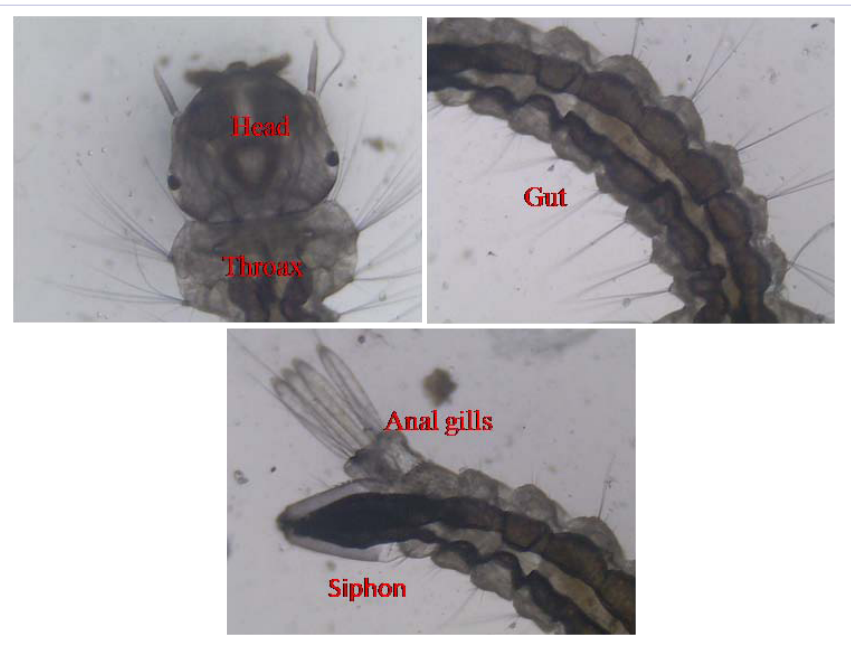

Photomicrograph taken using motic microscopy at $4 \mathrm{X}$

Figure 1: Different morphological variance of Aedes aegypti larvae
$90 \%$ respectively. As presented in [Table 1] there is less lethal concentration is required to produce maximal mortality against all four instar of $A$. aegypti. The $\mathrm{LC}_{50}$ and $\mathrm{LC}_{90}$ values is determined to the corresponding developmental stages were 2.64 to $4.68 \mathrm{mg} /$ $\mathrm{mL}$ and 6.24 to $8.33 \mathrm{mg} / \mathrm{mL}$ against all four instars of $A$. aegypti.

\section{Non- Toxicity Assay}

The Cladoceran, Moina micrura was analyzed its mortality after $24 \mathrm{~h}$ exposed to plant material, the cladoceran tested container was slowly shakened for confirm their viability. Tested strains were moved normal swimming even after exposure to plant materials at different concentration. It confirms that $M$. zapota has been eco-friendly to the environment and non-target aquatic insect.

\section{Discussion}

Mosquitoes are vector caused transmitted disease among human populations. Mosquito control is very important crucial role in world wide especially in tropical and subtropical region. Mosquito control is very effective at their larval stage when compared to Adult, because it is easy to deal with them habitat. Vector mosquitoes are well developed resistance to chemical insecticides and harmful effect on environment and other non target aquatic insects. In this connection, Environmental protection Agency (EPA) and World Health Organization (WHO) have result released in renewed interest in the development and use of botanical pesticides as one of an alternative resources or a tool for integrated vector management programs [28]. In this regards many researchers have been reported the effectiveness of plant extracts against mosquito larvae. Hence in this concern the plants synthesize a primary and secondary molecules to defend themselves against insect attack [29]. Among these, secondary metabolites such as terpenic metabolites, phenols, alkaloids and cyanogenic glycosides. Similarly the proteins are also involved in the defensive capabilities of many green plants have been reported [30]. Such as proteins include digestive enzyme inhibitors, chitinases, vicilins, lectins and lectin-like proteins, these proteins have potential use as naturally occurring insecticide agents against pests and insect control [31]. In this connection, A number of earlier investigators have been also examined the effect of aqueous extracts (distilled water, tap water and saline extract) of different parts from a variety of plants on various and selected developmental stages of one or two species of mosquito [32-36]. Among these studies Villanueva et al. [35] screened fourteen different plants parts and family, reported that the aqueous extract of the roots from $S$. nigrescens were conducted to evaluate seasonal variation in larvicidal activity with different parts, among which several parts, only crushed root extracts has been elicit maximum mortality rate of $83-100 \%$ against $A$. aegypti larvae. Similarly the few investigators also attempt to extract the bioactive compound with nine different plants and their parts using inorganic solvents, among the different solvent extraction, the methanol extract of $N$. nucifera bring about the maximum mortality rate against $A$. stephensi [37]. By conversely, Chowdhury et al. [38] extracted the bioactive compounds from Solanum villosum berry using distilled water and five different organic solvents and obtained the higher 
mortality to the aqueous extract when compared to other all organic solvent extracts against third-instar larvae of $A$. aegypti.

In the present study, for the first time the crude protein kernel extract from the M. zapota was found to be an effective larvicidal activity without affect the non target aquatic zooplankton and its evident from stronger larvicidal effects by impose $100 \%$ mortality of all four larval instars of $A$. aegypti within $24 \mathrm{~h}$ of exposure. Especially the first and second instar of this species were more susceptible and bring $100 \%$ mortality to the extract at the 6 to $8 \mathrm{mg} / \mathrm{ml}$, when compared to other larval developmental stages. In a similar study [39] were reported likewise that, the soapnut $S$. emarginatus has inflicted potent antimosquito activity against all the developmental stages of $A$. aegypti than other mosquito strains of $C$ quinquefasciatus especially fourth stage larvae and pupae was has less susceptible of soap nut extract. By contrast the Ramanibai et al. [40] were reported the strongest Ovicidal, larvicidal and pupicidal activity of $A$. squamosa aqueous soluble extract against all the developmental stages of $A$. aegypti, particularly all the larval instar. Here the hemolytic activity of $M$. zapota seed protein has ability to lytic activity to all the veretebrate RBC tested with efficient larvicidal activity of $A$. aegypti. The complementary studies were also reported by Rama Devi et al. [41] the Hemolytic lectin from Acacia Melanoxylon has ability to bring forth maximum mortality against $A$. aegypti. In this same connection reported Pterocarpus osun and Bosqueia angolensis hemagglutinin crude seeds protein extracts did not cause mortality against Culex sp. But in the case of hemolytic $M$. zapota seed protein had efficient larvicidal activity against $A$. aegypti it may be based on the carbohydrates specificity binding domain on gut epithelial cells to bring mortality to the larvae. Hence in this bioassay to confirm that, this is the first report $M$. zapota seed protein has potent larvicidal agent with hemolytic properties. The tested plant material was also noted that it couldn't able to reproduce mortality with active survivability against Cladocera, Moina micrura species when exposure to the plant materials at recommended concentration. The similar studies Ramanibai et al. [40] were also reported that the $A$. squamosa seed extract also not affected tested aquatic insect $C$. costatus at their tested concetration. In addition Koodalingam et al. [39] were also reported same studies with some disadvantage antimosquito activity of $S$. emarginatus has produced mortality against two non target aquatic organisms tested, Chironomus costatus (fourth instar larvae) at $\mathrm{LC}_{50} 5.71$ and $\mathrm{LC}_{50} 4.78$ and for Diplonychus rusticus (first instar nymphs) at $\mathrm{LC}_{50} 9.29 \mathrm{LC}_{50}$ 8.26 for 24 and $48 \mathrm{~h}$ exposed for 24 and $48 \mathrm{~h}$ exposed. But in our studies the M. zapota seed has not produced any mortality at tested concentration. In addition the similar study were also reported by that, crude extract of the four selected plants extracts at the studied concentrations did not produce any harmful effect on non-target organisms.

In conclusion, our study reveals that the larvicidal activity of hemolytic crude protein extracts of $M$. zapota seed bring out predominant mortality rate when dose dependently increased concentration against all the four instar larvae of $A$. aegypti under the laboratory condition without affect non-target aquatic strain. It is clearly demonstrate that the above finding of $M$. zapota seed protein can serve as a potent larvicide agent against A. aegypti larvae. Further analysis to be taken to purify the larvicidal molecules from plant seed crude protein for mosquito control under in vitro condition. Therefore the present study suggests that the active ingredients of this protein to be utilized, if possible, in preparing commercial product formulation as a mosquito larvicidal.

\section{Acknowledgments}

We acknowledge UGC-UPE-PHASE II, New Delhi (No. 2013/ $\mathrm{PFEP} / \mathrm{C} 3 / 199$ ) for financial support.

\section{References}

1. Hotez PJ, Remme JH, Buss P, Alleyne G, Morel C, Breman JG. Combating tropical infectious diseases: report of the disease control priorities in developing countries project. Clin Infect Dis. 2004;38(6):871-8.

2. World Health Organization. Vector-borne diseases. Geneva. 2016. Available from: http://www.who.int/mediacentre/factsheets/ fs387/en/

3. National Vector Borne Disease Control Programme (NVBDCP). Dengue Cases and Deaths in the Country. 2016. http://nvbdcp.gov.in/ dengue6.html.

4. Federici BA1, Park HW, Bideshi DK, Wirth MC, Johnson JJ, Sakano Y, Tang M. Developing recombinant bacteria for control of mosquito larvae. J Am Mosquito Contr. 2007;23(2 Suppl):164-75.

5. Isman MB. Plant essential oils for pest and disease management. Crop Protection. 2000;19:603-608.

6. BW Nugroho, RA Edrada, V Wray, L Witte, G Bringmann, M Gehling, P Proksch. An insecticidal rocaglamide derivatives and related compounds from Aglaia odorata (Meliaceae). Phytochemistry.1999;51(3):367-376.

7. Duranti M, Barbiroli A, Scarafoni A, Tedeschi G, Morazzoni P. One step purification of Kunitz soybean trypsin inhibitor. Protein Expres Purif. 2000;30(2):167-70.

8. Richa KW, Theerapong T, Soottawat B, Saroat R. Three-phase partitioning of trypsin inhibitor from legume seeds. Process Biochem. 2009;44(12):1307-14.

9. Macedo ML, Damico DC, Freire Md, Toyama MH, Marangoni S, Novello JC. Purification and characterization of an N-acetylglucosaminebinding lectin from Koelreuteria paniculata seeds and its effect on the larval development of Callosobruchus maculatus (Coleoptera: Bruchidae) and Anagasta kuehniella (Lepidoptera: Pyralidae). J Agric Food Chem. 2013;51(10): 2980-2986.

10. Powell KS, Spence J, Bharati M, Gatehouse JA, Gatehouse AM. Immunohistochemical and development studies to elucidate the mechanism of action of the snowdrop lectin on the rice brown planthopper Nilaparvata lugens (Stal.). J Insect Physiol. 1988;44(78):529-539.

11.Zhu-Salzman K, Shade RE, Koiwa H, Salzman RA, Narasimhan M, Bressan RA, et al. Carbohydratebinding and resistance to proteolysis control insecticidal activity of Griffonia simplicifolia lectin II (GSII). Proc Natl Acad Sci U S A. 1998;95(25): 15123-15128.

12.Zhu-Salzman K, Salzman RA. Functional mechanics of the plant defensive Griffonia sinplicifolia lectin II: resistance to proteolysis is independent of glycoconjugate binding in the insect gut. J Econ 


\section{Entomol. 2001;94(5):1280-1284.}

13. Napoleão TH, Emmanuel VP, Thâmarah AL, Nataly DLS, Roberto AS, Coelho LCBB, et al.Effect of Myracrodruon urundeuva leaf lectin on survival and digestive enzymes of Aedes aegypti larvae. Parasitol Res. 2012;110(2):609-616. doi: 10.1007/s00436-011-2529-7.

14. Coelho JS, Santos ND, Napoleão TH, Gomes FS, Ferreira RS, Zingali RB, et al. Effect of Moringa oleifera lectin on development and mortality of Aedes aegypti larvae. Chemosphere. 2009;77(7):934-8. doi 10.1016/j.chemosphere.2009.08.022.

15. Mathew AG, Lakshminarayana S. Polyphenols of immature sapota fruit. Phytochemistry. 1969;8(2):507-9.

16.Misra, G., Nigam, S.K., Mitra, C.R., 1969. Constituents of Mimusops manilkara leaves and saponins of mimusops seed kernels. Phytochemistry. 8, 255-6.

17. Ahmed R, Rashid F, Ahmed VU, Mohammad FV, Noorwala M, Bibi N, et al. Saponins from the seeds of Achras sapota. J Asian Nat Prod Res. 2008;10(1-2):7-16

18. Kamaraj C, Rahuman AA, Bagavan A, Elango G, Zahir AA, Santhoshkumar T. Larvicidal and repellent activity of medicinal plant extracts from Eastern Ghats of South India against malaria and filariasis vectors. Asian Pac J Trop Med. 2011;4(9):698-705. doi: 10.1016/S1995-7645(11)60177-6

19. Nair R, Chanda S. Antimicrobial activity of Terminalia catappa, Manilkara zapota and Piper betel leaf extract. Indian J Pharm Sci. 2008;70(3):390-3. doi: 10.4103/0250-474X.43012.

20. Keneria M, Bravalia Y, Vaghasiyan Y, Chanda S. Determination of antibacterial and antioxidant potential of some medicinal plants from Saurashtra Region, India. Ind J Pharmaceut Sci. 2009;71(4):406-12. doi: 10.4103/0250-474X.57289.

21.Chanda, SV., Nagani, KV., 2010. Antioxidant capacity of Manilkara zapota L. leaves extracts evaluated by four in vitro methods. Nat Sci. 8 $260-26$

22. AL-Mamun MA, Akter Z, Uddin MJ, Ferdaus KM, Hoque KM, Ferdousi $\mathrm{Z}$, et al. Characterization and evaluation of antibacterial and antiproliferative activities of crude protein extracts isolated from the seed of Ricinus communis in Bangladesh. BMC Complement Altern Med. 2016;16:211. doi: 10.1186/s12906-016-1185-y.

23.Zeng G, Li C, Zhang X, Teng Y, Dong W. Efficient protein extraction method from apple leaves for apple proteomic analysis using twodimensional electrophoresis analysis. Se Pu. 2009;27(4):484-8.

24. lowery OH, Rosebrough NJ, Farr AL, Randall RJ. Protein measurement with the folin phenol reagent. J Biol Chem. 1951;193(1):265-75.

25. Correia MT, Coelho LC. Purification of a glucose/ mannose specific lectin, isoform 1, from seed of Cratylia mollis Mart. (Camaratu Bean). Appl Biochem Biotechnol. 1995 ;55(3):261-73.

26. World Health Organization. Report of an WHO informal consolation on the testing of insecticides.1996. CTD/WHO/PES/IC/96.1.
27.OECD., 2004. Organisation for Economic Co-operation and Development guideline for testing of chemicals. Daphnia sp. Acute Immobilisation Test, TestMethod 202, Paris, France.

28. Isman MB. Neem and other botanical insecticides: barriers to commercialization. Phytoparasitica. 1997. 25:339

29. Bate NJ, Rothstein SJ. C6-volatiles derived from the lipoxygenase pathway induce a subset of defense-related genes. Plant Journal. 1998;16(5):561-9.

30. Uchoa AF, DaMatta RA, Retamal CA, Albuquerque-Cunha JM, Souza SM, Samuels RI, et al. Presence of the storage seed protein vicilin in internal organs of larval Callosobruchus maculatus (Coleoptera: Bruchidae). Journal of Insect Physiology. 2006;52(2):169-78.

31.Vasconcelos IM, Oliveira JTA. Antinutritional properties of plant lectins. Toxicon. 2004;44(4):385-403.

32. Murugan, K., Jeyabalan, D., 1999. Effect of certain plant extracts against the mosquito, Anopheles stephensi Liston. Curr Sci. 76, 631-633.

33. Chansang U, Zahiri NS, Bansiddhi J, Boonruad T, Thongsrirak P, Mingmuang J, et al. Mosquito larvicidal activity of aqueous extracts of long pepper (Piper retrofractum Vahl) from Thailand. J Vector Ecol. 2005;30(2):195-200.

34. Khanna VG, Kannabiran K. Larvicidal effect of Hemidesmus indicus, Gymnema sylvestre and Eclipta prostrata against Culex quinquefasciatus mosquito larvae. Afr J Biotechnol. 2007;6(3):307311.

35. Villanueva RF, Gaona OJG, Perez MAR. Larvicidal Effect of Medicinal Plants Against Aedes aegypti (L.) (Diptera: Culicidae) in Mexico. BioAssay. 2008;3:7.

36. Chowdhury N, Ghosh A, Chandra G. Mosquito larvicidal activities of Solanum villosum berry extract against the dengue vector Stegomyia aegypti. BMC Complement Altern Med 2008;8:10. doi: 10.1186/14726882-8-10.

37. Santhoshkumar T, Rahuman AA, Bagavan A, Kirthi AV, Marimuthu $S$, Jayaseelan $C$ et al. Efficacy of adulticidal and larvicidal properties of botanical extracts against Haemaphysalis bispinosa, Hippobosca maculata, and Anopheles subpictus.Parasitol Res. 2012 ;111(4):183340.

38. Chowdhury N, Ghosh A, Chandra G. Mosquito larvicidal activities of Solanum villosum berry extract against the dengue vector Stegomyia aegypti. BMC Complement Altern Med.2008;8:10.

39. Koodalingam A, Mullainadhan P, Arumugam M. Antimosquito activity of aqueous kernel extract of soapnut Sapindus emarginatus: impact on various developmental stages of three vector mosquito species and nontarget aquatic insects. Parasitol Res. 2009;105(5):1425-34. doi: $10.1007 / \mathrm{s} 00436-009-1574-\mathrm{y}$.

40. Ramanibai R, Parthiban E, Boothapandi M. Effect of seed kernel aqueous extract from Annona squamosa against three mosquito vectors and its impact on non-target aquatic organisms. Asian Pac J 